\title{
FORUM
}

\section{Control of Phlebotomine (Diptera: Psychodidae) Leishmaniasis Vectors}

\author{
Sthenia S A Amóra ${ }^{1}$, Claudia M L Bevilaqua ${ }^{1}$, Francisco M C Feijó ${ }^{2}$, Nilza D Alves², \\ MicheLLINE DO V MACIEL ${ }^{1}$ \\ ${ }^{1}$ Programa de Pós-Graduação em Ciências Veterinárias, Univ. Estadual do Ceará, Av. Paranjana 1700, Campus do \\ Itaperi, 60740-000, Fortaleza, CE; ${ }^{2}$ Curso de Medicina Veterinária, Univ. Federal Rural do Semi-Árido, Rod BR 110 \\ km 47, Presidente Costa e Silva, 59625-900, Mossoró, RN
}

Edited by Álvaro Eiras - UFMG

Neotropical Entomology 38(3):303-310 (2009)

Controle de Flebotomíneos (Diptera: Psychodidae) Vetores de Leishmanioses

\begin{abstract}
RESUMO - Os flebotomíneos são vetores de importância médica e veterinária, podendo transmitir leishmanioses, bartoneloses e algumas arboviroses. A adaptação de algumas espécies a locais que passaram por modificações humanas as aproxima dos domicílios, podendo facilitar a transmissão das doenças, e as estratégias adotadas para seu controle têm sido controvertidas. No tocante às leishmanioses, por exemplo, o que sustenta a utilização do controle vetorial e de reservatórios como estratégias de intervenção é a conjectura de que a incidência de infecção em humanos está diretamente relacionada ao número de cães infectantes e a fatores entomológicos. Dessa forma, o controle do vetor pode então oferecer solução menos onerosa e mais prática, o que conduziria a medidas preventivas eficazes em um maior número de focos de leishmaniose. Não obstante, na complexidade dos fatores envolvidos, o controle químico continua sendo indispensável e o uso de inseticidas biológicos e plantas inseticidas, por exemplo, representam áreas de estudo a serem incentivadas e desenvolvidas, pois apresentam resultados promissores. A análise em questão representa uma oportunidade de avaliação das medidas até então adotadas, principalmente em relação aos métodos e à eficácia dos componentes entomológicos dos programas de controle das leishmanioses.
\end{abstract}

\section{PALAVRAS-CHAVE: Antropozoonose, Lutzomyia, Phlebotomus}

\begin{abstract}
Phlebotomines are of medical and veterinary concern as they vector leishmaniasis, bartonellosis and some arboviruses. The adaptations of some species to places modified by humans bring these vectors into contact with dwellings, which can facilitate disease transmission, and the vector control strategies adopted have rendered controversial results. Regarding leishmaniasis, for instance, which vector and reservoirs control can be effective, there is an assumption that the incidence of human infection is directly related to the number of infectious dogs, as well as to entomological factors. Therefore, vector control can provide a cheaper and more practical solution to prevent cases of leishmaniasis. Nevertheless, due to the complexity of the factors involved, chemical control is still essential, and biological insecticides and insecticide plants, for example, represent areas for study that should be encouraged and developed since they show promising results. This paper summarizes the control strategies adopted so far, especially the methods and efficiency of the entomological components of leishmaniasis control programs.
\end{abstract}

KEY WORDS: Sandfly vector, anthropozoonosis, Lutzomyia, Phlebotomus

Phlebotominae are of medical and veterinary concern as they vector leishmaniasis, bartonellosis and some arboviruses (Pessoa et al 2007), such as fleboviruses (Xu et al 2007), flaviviruses, orbiviruses (Traore-Lamizana et al 2001) and vesiculoviruses (Comer \& Tesh 1991). Leishmaniasis is an anthropozoonosis of great public health concern affecting more than 80 countries around the world. In Brazil, leishmaniasis is an endemic disease vectored mainly by species belonging to Lutzomyia (Monteiro et al 2005). The illnesses show a peridomiciliary transmission pattern, mainly because some vector species became adapted to modified environments. Also, the disordered human occupation of hillsides and encroachment into forested areas, enables the disease to spread in an extraforest cycle (Madeira et al 2003). This reduces vectors' ecological space and facilitates epidemics (Monteiro et al 2005). 
The Brazilian surveillance and control manuals of Visceral Leishmaniasis (VL) (Ministério da Saúde 2006) and the American Cutaneous Leishmaniasis (ACL) (Ministério da Saúde 2007) advise entomological inspection to obtain qualitative and quantitative information on phlebotomines, aiming to verify their presence in areas with and without human leishmaniasis cases. Control measurements are based on the residual use of pyrethroids in capture areas connected to human cases of the disease, but they have been innefective in reducing VL incidence (Amóra et al 2006). Therefore, it is necessary to evaluate the actions developed to control these vectors, especially their real effectiveness (Oliveira \& Araújo 2003).

The objective of this paper is to review the current knowledge on the control of phlebotomines, ranging from conventional measures to the most recent technologies, to help health authorities to choose the most efficient and costeffective strategy for each region.

\section{Phlebotomines}

Phlebotomine sandflies, vectors of Leishmania sp. are represented by more than 40 species in the Old World and 30 species in the Americas, which vector Leishmania spp. (Alexander \& Maroli 2003). They are known to prefer living in forests, secondary forests and areas of calcareous rocks. Their adaptations bring these vectors close to dwellings and may facilitate the transmission of such diseases (Dias et al 2007). Thus, the wild endemic pattern has been replaced by the spread of the disease associated with environmental modifications, disordered human occupation and substandard living conditions. The disease is spreading in both rural and urban areas, exceeding old defined geographic limits and becoming a serious public health problem (Dantas-Torres \& Brandão-Filho 2006). On one hand, the vector adapts easily to the peridomestic conditions of impoverished areas, exploiting the accumulation of organic matter produced by domestic animals and poor sanitary conditions. On the other hand, stray dogs wandering in the periphery of cities can become infected by contact with wild reservoirs and can spread the infection to other dogs and humans when back to the city (Costa et al 2007).

In Brazil, the study of phlebotomines as vectors started in 1934, when Henrique Penna suggested that the largest focus of VL was in the Northeast, particularly in the state of Ceará. At that time, Evandro Chagas, who was studying VL in the states of Sergipe, Pará and Ceará, also made the important observation that the hematophagous insect most often found in intra- and peri-domicile areas was Lutzomyia longipalpis Lutz \& Neiva. Since then, the presence of Lu. longipalpis has been associated with VL cases in an extensive area of the Americas, from Mexico to Argentina (Lainson \& Rangel 2005, Nascimento et al 2007). In the last ten years, the urban spread of leishmaniasis, evidenced by epidemic outbreaks in several Mediterranean regions and Latin American countries (Maroli \& Khoury 2004) including Brazil, is an aspect that must be considered in the disease epidemiology (Monteiro et al 2005).

Leishmaniasis expansion resulted in the establishment of new endemic areas, demonstrating the vectors adaptability to modified natural environments (Madeira et al 2003), what transferred a disease that was almost exclusively rural to a wider distribution in urban areas. The most important determinants of VL epidemical levels in urban centers are the proximity of the reservoir $(\mathrm{dog})$ and the man, the increase in vector density, accentuated deforestation and constant migration flow. Other factors must be involved, specifically the potential transmission, that results from vector density and infection rate, besides the vulnerability of susceptible people toward developing the disease. Entomological and serological surveys in dog populations in endemic areas revealed the high prevalence of LV in dogs, and an abundance and dominating presence of vector, increasing the risks of disease transmission to man (Monteiro et al 2005).

Phlebotominae are crepuscular and nocturnal, remaining in their niche shelters for most of the day (Lainson \& Rangel 2005). Their occurrence in some areas may also be related to climatic factors like temperature, rainfall and relative humidity. According to this hypothesis, phlebotomines benefit from moderate rainfall during the rainy season, but flooding is harmful because it destroys their breeding areas and kills the pupae in the soil (Dias et al 2007). In addition, the lower temperatures and greater food availability to the larvae with the fallen leaves in the autumn may stimulate mass pupation, as observed in the state of São Paulo (Odorizzi \& Galati 2007). This climatic influence is also noticed in Northeast of Brazil, a fact pointed out by Alencar et al (1956) during their research in the Vale do Jaguaribe, CE, where they observed higher vector concentration along the riverbanks, where humidity and heat were noticeable.

\section{Phlebotomine Control}

Studies focusing on eliminating stray dogs were controversial, at least when used separately from vector control (Costa et al 2007). According to the VL manual (Ministério da Saúde 2006), Brazilian municipalities without VL cases and with an average of 2.4 cases in five years are classified as having sporadic transmission. Surveillance, vector population dynamic and control chemicals are not indicated. Here, the presence of the vector is essential in maintaining the disease cycle, but nothing is done to control its population; the center of the control measures are still on the canine reservoir, proving once more that these measures are not integrated and that this is probably the chief cause of the failure of the Leishmaniasis control program.

In this situation, dog euthanasia is unproductive because the raise in the phlebtomine sandfly population will further increase the risk of humans being bitten, especially considering the adaptation of Lu. longipalpis to the domiciliary environment, where it can find shelter and food (Ximenes et al 2007). The VL vectors dietary habits may have implications for the disease epidemiology in urban and peri-urban areas where vector females are deprived of their vertebrate hosts. Also, the availability of rearing sites in close contact with people can promote human infection (Bongiorno et al 2003).

In addition, if VL control had been efficient in the $82 \%$ 
of the Brazilian municipalities with sporadic transmission, the risk of increasing the disease prevalence would be much smaller. Adequate initial control would be helpful even in areas with moderate and intense VL transmission, averaging between 2.4-4.4 and more than 4.4 cases in five years, respectively. In the pre-rain period before the vector population growth, when immatures are still in development and are susceptible to insecticides, no chemical control measures are recommended, allowing insects to complete their life cycle and ensure their survival (Ministério da Saúde 2006). However, the guidelines available for ACL control specifically indicates the period before or immediately after the rains as ideal for chemical spraying targeting the vector (Ministério da Saúde 2007).

However, several experiments have demonstrated the effectiveness of vector control in several situations. What underpins the use of vector and reservoir control as leishmaniasis intervention strategies is the belief that the incidence of human infections are directly related to the number of infective dogs and entomological factors (Costa et al 2007). Vector control may offer a less expensive and more practical solution, which would enable more efficient preventive measures in a greater number of sites where leishmaniasis is present (Maroli \& Khoury 2004). However, the vector control urged by the World Health Organization so far is focused only on capture and residual pyrethroid application when human cases are reported (MS 2005). Since little is known on the reproduction and daytime resting places of vector species, current control measures do not affect insects in their immature stages (Pessoa et al 2007), making vector control entirely dependent on combating full-grown insects (Alexander \& Maroli 2003). Even in these cases, the efficiency of such strategies targeting adult vectors were rarely investigated (Gontijo \& Melo 2004).

Environmental changes. Each environmental change, whether by natural phenomenon or human intervention, alters the ecological balance and the context in which vectors and parasites develop and transmit diseases (Pessoa et al 2007). Phlebotomines reproduce in dark places, such as tree cracks, in the presence of humus and moisture. The principle of environmental management is to make it unsuitable for the vector to live and reproduce (Kishore et al 2006). Therefore, the target areas for environmental management should be the domestic animal shelters built close to human dwellings, the lack of good hygienic conditions in the peridomicile and the proximity of small wooded areas, which are often observed in the rural settings in many regions of Brazil (Teodoro et al 2001). These areas are associated with moist soils and accumulated organic matter, favoring the phlebotomine breeding sites and allowing for vector concentration in peridomiciliary environments (Casanova 2001).

The recommended control measures for ACL (Ministério da Saúde 2007) are clearer and more effective in achieving control of vector outbreaks when compared to the measures for VL control (Ministério da Saúde 2006). Measures include pruning trees in order to increase sunshine, thereby decreasing soil shading and preventing favorable conditions (temperature and humidity) for the development of sand fly larvae (Ministério da Saúde 2007).
Mestre \& Fontes (2007) stated that accentuated deforestation is one of the main reasons for VL epidemic outbreaks in large cities. An intensive investigation of the ecology of these phlebotomines should be part of the routine public health service activity, mainly in regions of endemic leishmaniasis (França-Silva et al 2005). The understanding of the interactions between changes of the urban environment and the sand flies vectors is a prerequisite for the development of appropriate actions of prevention and control strategies (Gontijo \& Melo 2004).

Thus, one alternative for phlebotomine control can be the modification of their ideal developmental habitat, by microclimate and environment changes. As an example, the efforts to reorganize and clean peridomicile areas, as well as ridding dwellings, domestic animal shelters and other rearing environments of insects, were effective in phlebotomine control in the municipality of Doutor Camargo, PR, South of Brazil; the frequency of phlebotomines on peri- and intradomicile areas in an endemic area of ACL was substantially reduced (Teodoro et al 2004). Pessoa et al (2007), after removing tree stumps from a wood-producing forest in the Amazon, observed that both the vector abundance and the ratio of female phlebotomines infected by Leishmania declined. However, there are still few studies on the effect of environmental changes on arthropods, especially on public health.

Pesticides. The first attempt to control phlebotomines with a pesticide used 5\% dichlorodiphenyltrichloroethane (DDT) in areas of bartonellosis in Peru in 1944, with the spraying of huts targeting Lutzomyia verrucarum Townsend for a week (Hertig $\&$ Fairchild 1948). In the 1950s and 60s, the intensive use of DDT to eradicate malaria, indirectly affected the leishmaniasis prevalence in several localities, but they soon regained the initial levels of prevalence once sprayings were suspended (Kishore et al 2006). In Brazil, DDT was first used in 1954 against an ACL focus in Rio de Janeiro (Nery-Guimarães \& Bustamante 1954), and later used against Lu. longipalpis in Ceará (Alencar 1961). However, control levels were unsatisfactory, probably due to the failure to apply pesticides at a proper time (Lainson \& Rangel 2005).

However, restrictive measures against the use of DDT were first taken in 1971 due to the decisive evidence of the negative side-effects on non-target hosts and to the environment (Lainson \& Rangel 2005, Kishore et al 2006), leading to DDT and benzene hexachloride (BHC), and other organochlorines withdrawal from the market for agricultural application in the country in 1985. Nevertheless, these insecticides continued to be used in public health campaigns and in emergencial cases in agriculture, at the discretion of the Agriculture Ministry (D'amato et al 2002).

Nowadays, attention focuses on synthetic pyrethroids (Lainson \& Rangel 2005). Pyrethroids have low to moderate toxicity to mammals, are not excessively volatiles and have high insecticide activity. In addition, their effects are independent of insect behavior and can be effective even at low concentrations (Kishore et al 2006). Phlebotomine control efforts are made with these synthetic compounds in dwellings and out-buildings. However, their effectiveness, residual activity and amount required vary in different 
endemic areas (Gontijo \& Melo 2004). The use of pyrethroids against phlebotomines was prompted by their successful utilization in impregnated mosquito nets for malaria mosquito control. This strategy is advantageous as it can be used at a domestic/individual level without any major side-effects, while also controlling other biting insects (Maroli \& Khoury 2004). In Brazil, investigation on this issue is limited, with only one single controlled study testing deltamethrin in intra- and peri-domicile areas for ACL vector control in the Espirito Santo state. Although a good residual effect was observed for 12 months post-treatment, the insecticide was only able to reduce the phlebotomine density in households (Falcon et al 1991).

All above mentioned control strategies seem feasible, but the insect-vectored disease prevention is very difficult in practice, especially when associated with the existence of domestic and wild reservoirs and environmental aspects (Gontijo \& Melo 2004). Therefore, one strategy would be the removal of domestic animals from the intra-domicile at night to reduce the phlebotomine attraction to this environment (Ministério da Saúde 2007).

An understanding of the interactions between urban environmental changes and phlebotomine vectors is a prerequisite for the development of appropriate preventive actions and control strategies. In Brazil, these actions have always been discontinued for various reasons, such as funding problems and a scarcity of properly trained people, and have not attained the expected results, with re-infestations and the reappearance of VL cases in humans and dogs (Gontijo \& Melo 2004).

It is also important to note that in rural areas where dwellings are more dispersed and surrounded by large reservoir populations, chemical residues sprayed in houses can be ineffective. Treatment in such conditions may also be a problem due to logistics (Maroli \& Khoury 2004), and the recommended treatment of all dwellings where VL transmission is reported might be difficult to achieve (Ministério da Saúde 2006). The recommendations available for ACL management are more specific, indicating that the spraying area should include an initial radius of $500 \mathrm{~m}$ around the domiciles where human cases are reported, and this distance can be extended to a kilometer if dwellings are spread apart (Ministério da Saúde 2007).

In summary, numerous phlebotomine control efforts have focused on the use of chemical insecticides, but these measures, although initially attractive, are generally not permanent. Impoverished living conditions, premature discontinuation and/or use in inappropriate periods and environmental risks of insecticide applications in natural environments are all factors hindering phlebotomine control (Teodoro et al 2007).

Deltamethrin impregnated collars. Experiments have also been tried based on vector control centered on the canine reservoir, like the recent experiments with deltamethrin impregnated collars (DIC), which have shown promising results in protecting the animals and lowering the transmission rates (Gontijo \& Melo 2004). In VL endemic areas in Italy (Maroli et al 2001) and Iran (Mazloumi Gavgani et al 2002), the use of DIC for dogs during the whole transmission season lowered the infection risk by Leishmania infantum. Other studies have also confirmed the anti-biting effect of DIC against $L u$. longipalpis and Lutzomyia migonei, with a reduction of $81 \%$ to $100 \%$, for 35 weeks. It is believed that the epidemiologic effect of DIC is instantaneous because not only the rate at which dogs are bitten is reduced, but also the death rate of phlebotomines that try to feed on dogs with DIC is high (David et al 2001). However, no significant differences were observed in control efficiency between the use of DIC and animal euthanasia in a modeling over a period of five years, and no statistical differences were observed between collar-wearing and control dogs in acquiring VL (Reithinger et al 2004).

In light of this, the decision to include mass DIC application in leishmaniasis control programs in Brazil will depend on its practical applicability in the field, namely voluntary use, efficient exchange of collars and accessible intervention cost (Dantas-Torres 2006). Longitudinal studies demonstrating the effectiveness of this implementation as a control measure are necessary in order to stop the domestic transmission cycle (Ministério da Saúde 2006).

Insecticidal plants. The need for more efficient and safer methods to control insects has also stimulated the search for new insecticides in plants (Nogueira \& Palmério 2001). Plants have being important sources of active compounds against insects, such as pyrethroids (pyrethrin and allethrin) and rotenoids. Studies have shown that some phytochemicals have a toxic effect against insect adults and larvae by interfering in their growth, development and/or reproduction, or by producing attractive or repellent scents (IMCR Bulletin 2003). The neem (Azadirachta indica) oil repellent activity for Phlebotomus papatasi Scopoli was shown more effective than N-diethyl phenyl acetamide (DEPA) when used for three days at concentrations of $1 \%$ and 2\% (Srinivasan \& Kalyanasundaram 2001). In Brazil, the effects of the neem active molecule azadirachtin A on the development, mortality and metamorphosis of $L u$. longipalpis were also studied; the concentrations of 0.1 , 1.0 and $10.0 \mu \mathrm{g}$ of azadirachtin $/ \mathrm{mg}$ of diet significantly increased larval mortality. Concentrations of 0.1 and 1.0 $\mu \mathrm{g}$ halted metamorphosis, and $10 \mu \mathrm{g} / \mathrm{mg}$ also affected the molt from second to third instars. These results indicate that azadirachtin is a potent growth inhibitor of $L u$. longipalpis (Coelho et al 2006).

Many more plant species are described in the literature as possessing insecticidal and/or repellent activity. LuitgardsMoura et al (2002) tested the effects of Antonia ovata and Derris amazonica on adults of Lu. Longipalpis, observing death rates of $80 \%$ and $100 \%$, respectively, $72 \mathrm{~h}$ after exposure. The repellent and feeding-inhibiting effect of the garlic oil (Allium sativum) was also evaluated on P. papatasi females. At $1 \%$, the oil had a repellent effect of $97 \%$ and an anti-feeding effect of $100 \%$ (Valerio \& Maroli 2005). Many other studies have been carried out to evaluate the biological activity of plant components against many pathogens and arthropods (Shaalan et al 2005). However, many questions about the toxicity of the active ingredients of these plants still need to be clarified before these plant extracts can be used in applied control. 
Bioinsecticides. The indiscriminate use of insecticides induces insect resistance and disrupts food chains, affecting the population density of non-target species. These factors, associated with the many diseases transmitted by dipterans, call for the development of new control strategies. The growing global awareness for food quality forces countries that export agricultural products to reduce pesticide use, increasing the need for new biotechnological solutions, particularly the use natural resources (Campos et al 2005). Bioinsecticides are generally more specific, showing no or low toxicity to non-target animals and are environmental friends (Hynes \& Boyetchko 2006).

An alternative is Bacillus thuringiensis var. israelensis or Bacillus sphaericus, currently used to control mosquito larvae and black flies. The efficiency of entomopathogens against phlebotomines was first demonstrated for $B$. thuringiensis on P. papatasi and Lu. longipalpis (De Barjac et al 1981), and later for B. sphaericus on Phlebotomus martini Parrot (Robert et al 1997). Larvae and pupae survivorship showed a dose dependent response when immatures were fed on a diet containing $B$. thuringiensis var. israelensis, being recommended as a control agent of $P$. papatasi (Wahba et al. 1999). Bacillus sphaericus was also tested and caused larval mortality, and reduced fecundity of the females emerged from the surviving pupae (Wahba 2000). However, especially in the case of $B$. thuringiensis, many questions need to be answered before this bacterium can be used in real settings, as product fermentation during manufacture, formulation problems and inadequate market research have been reported, which led to the withdrawal of the commercially available products from the market.

Besides Leishmania spp., Neotropical phlebotomines are also hosts to gregarines (Lewis et al 1970). Ascogregarina chagasi reduces both host longevity and fecundity, destroying Lu. longipalpis lab colonies (Dougherty \& Ward 1991). However, it is still questionable to what extent this parasite can be used for the biological control of phlebotomines (Lainson \& Rangel 2005).

Among the organisms that act as dipterans natural biological control agents, the entomopathogenic fungi in general present more efficient rates and exhibit more specificity on the target insect than chemical insecticides. The fungal species that attack several hosts should be favored in control programs because they can be used in several areas, such as Beauveria bassiana stands out (Barreto et al 2004). In Colombia, Warburg (1991) demonstrated that filter paper impregnated with $B$. bassiana conidia increased $P$. papatas $i$ and Lu. longipalpis adult mortality. However, the efficiency on Lutzomyia in laboratory tests could not be reproduced in later tests, although field studies confirmed the efficacy of this natural enemy in controlling mosquito adults (Reithinger et al 1997).

Recently, an intestinal nematode (Rhabditida, Steinernematidae) from $\mathrm{Lu}$. longipalpis was described in Minas Gerais, Brazil. Its life cycle is simultaneous to that of Lu. longipalpis and the transmission is direct. It is believed that stress conditions may increase host colonization by the parasite, which will consequently interfere with the insect normal development. The infectious ability of this nematode, its lethal effect on phlebotomines and no risk of vertebrate contamination make it a good candidate for biological control of Lu. longipalpis (Secundino et al 2002).

Studies on biological control of phlebotomines are still scarce and its practical application seems to be limited to adult VL vector control (Kishore et al 2006), since the employment of biolarvicides in the field is difficult due to the diversity of habitats in which this vector can reproduce.

Vaccines. Brazil (Universidade Federal Rural do Rio de Janeiro) developed the first vaccine in the world against canine VLdad. In field tests, this vaccine was able to protect 92-95\% of the treated dogs against VL (Borja-Cabrera et al 2002). Although this measure is focused directly on the canine reservoir, experimental studies have demonstrated that Lu. longipalpis females fed on vaccinated dogs can develop receptors for the antibodies produced by the vaccine antigen fucose-mannose ligand (FML), preventing new forms of Leishmania chagasi ingested by the insect in other blood meals (Saraiva et al 2006). This study was based on previous experiments to produce a "transmission blocker" vaccine against malaria (Arévalo-Herrera \& Herrera 2001).

The principle of this vaccine stands on the production of antibodies in the vaccinated host. These antibodies, after ingestion by the vector during the blood meal, are thought to block the parasite fertilization process in the vector by competing with Leishmania to bind to the vector's midgut, with significant results for $L$. infantum and L. chagasi (Saraiva et al 2006). These findings demonstrated that the vaccine is a potential vector transmission blocker, opening a new perspective for VL control through vector transmission blocking (Dantas-Torres 2006). The vaccine can then be indicated as a canine VL prophylactic measure in endemic and epidemic areas. However, there is still a lack of knowledge on the positive impact the vaccine can have on public health (Dantas-Torres 2006). For that reason, the Health Ministry has not adopted the use of this vaccine as a control measure in public health campaigns against canine VL in Brazil yet. Besides, studies conducted so far have not demonstrated a reduction in human VL incidence, and there is still no evidence of its cost-benefit ratio and effectiveness against canine reservoirs in public health programs (Werkhauser 2004).

Health education focused on phlebotomine control. In Brazil, the manuals of VL and ACL advocate health education activities and require their inclusion in all services that develop measures for leishmaniasis control, requiring the effective involvement of multi-institutional and multidisciplinary teams in order to articulate the work in the various units providing services (Ministério da Saúde 2006, 2007). Sherlock (1996) observed in VL transmission areas of Bahia State and other Brazilian regions, that poverty, malnutrition and high phlebotomine density in and around dwellings are associated with high numbers of domestic animals and poor sanitary conditions. This was also the case in Montes Claros, Minas Gerais, where habitants are mostly extremely poor, with inadequate garbage collection and sanitation, residents of low socio-economic levels, and with high coexistence with domestic animals. These characteristics result in organic matter accumulation, providing favorable conditions for disease 
transmission (Monteiro et al 2005).

Unfortunately, this scenario is kept unchanged and is reported elsewhere in Brazil (Várzea Grande, Mato Grosso) (Mestre \& Fontes 2007). The lack of preventive measures of the health services for early diagnosis and treatment of human $\mathrm{VL}$, and the use of curative rather than preventive strategies to fight VL, has brought alarming death rates (Costa et al 2007). This suggests that the lack of information about VL among the public at large, and among health professionals in particular, is a major drawback in reducing the severity of this disease. An aggravating contributing factor is the disorganization of public agencies and the constant replacement of vector control specialists by health agents, what causes a shortage of qualified staff for control work (Teodoro et al 2007).

Another critical point is the public educational material produced on leishmaniasis, which is not capable of conveying the threat posed by the disease in the context of its social and cultural environment (Pimenta et al 2007). In an analysis of the printed informative material on leishmaniasis, Luz et al (2003) alerted to the prevalence of an impositive writing and the reproduction of preconceptions from drawings and photographs. The scarcity of well-prepared educational and communication material for public health extension services points for the need for a critical reflection on the efforts to educate the public, particularly through new audiovisual approaches. Interdisciplinary studies can contribute to a better understanding of the disease in several fields of collective health, and health and video anthropology can provide better insight into the audiovisual production on leishmaniasis (Pimenta et al 2007).

So, because these vectors are linked to poor socioeconomic and sanitary conditions, and control measures must be systematically conducted, it is necessary to define public health policies that can resolve the existing distortions and inequalities in health standards. These should go beyond the current actions and find new alternatives, such as better access to education, improved habitation, higher income and nutrition, basic sanitation and environmental protection. All of these would have a new impact on the occurrence of the diseases discussed in here (Oliveira \& Araújo 2003). Health education can offer people simple knowledge of local vector reproduction sites and can result in a significant reduction in disease incidence. As is true for all diseases of public health importance, basic and general knowledge must be broadly disseminated (Kishore et al 2006). Through inexpensive alternatives and practical measures that can be incorporated into the routine of people living in high-risk areas, the incidence of leishmaniasis can be lowered. That means that more effective prevention and control of these vectors requires evaluation of the public health efforts effectiveness and the participation of community in their implementation (Teodoro et al 2007).

Conclusions. The analysis of the current scenario on leishmaniasis control in Brazil reveals a need for an in depth reflection on the implications of the health actions that are proposed and implemented for phlebotomine control, as well as the need to develop more efficient methods to control the vectored diseases. Due to the complexity of the factors involved, chemical control is still essential. However, the use of biological insecticides and insecticidal plants represents a fertile ground for further study, as promising results have been reported.

\section{References}

Alencar J E (1961) Profilaxia do calazar no Ceará, Brasil. Rev Inst Med Trop Sao Paulo 3: 175-180.

Alencar J E, Holanda D, Cavalcante J D N (1956) Leishmaniose visceral no Vale do Jaguaribe, Ceará, 1955. Rev Bras Malariol Doen Trop 8: 33-48.

Alexander B, Maroli M (2003) Control of Phlebotomine sandflies. Med Vet Entomol 17: 1-18.

Amóra S S A, Santos M J P, Alves N D, Gonçalves-da-Costa S C, Calabrese K S, Monteiro A J, Rocha M F G (2006) Fatores relacionados com a positividade de cães para leishmaniose visceral em área endêmica do estado do Rio Grande do Norte, Brasil. Cienc Rural 36: 1854-1859.

Arévalo-Herrera M, Herrera S (2001) Plasmodium vivax malaria vaccine development. Mol Immunol 38: 443-55.

Barreto R S, Marques E J, Gondim Jr M G C, Oliveira J V (2004) Seleção de Beauveria bassiana (Bals.) Vuill. e Metarhizium anisopliae (Metsch.) Sorok. para controle do ácaro Mononychellus tanajoa (Bondar). Sci Agric 61: 659-664.

Bongiorno G, Habluetzel A, Khoury C, Maroli M (2003) Host preferences of phlebotomine sand flies at a hypoendemic focus of canine leishmaniasis in central Italy. Acta Trop 88: 109-116.

Borja-Cabrera G P, Correia Pontes N N, Silva V O, Souza E P de, Santos W R, Gomes E M (2002) Long lasting protection against canine kala-azar using the FML-QuilA saponin vaccine in an endemic area of Brazil (São Gonçalo do Amarante). Vaccine 20: $3277-3284$

Campos R A, Arruda W, Boldo J T, Silva M V, Barros N M, Azevedo J L, Schrank A, Vainstein M H (2005) Boophilus microplus infection by Beauveria amorpha and Beauveria bassiana: SEM analysis and regulation of subtilisin-like proteases and chitinases. Curr Microbiol 50: 257-261.

Casanova C (2001) A soil emergence trap for collections of phlebotomine sand flies. Mem Inst Oswaldo Cruz 92: 273-275.

Coelho C A A, Souza N A, Feder M D, Silva C E, Garcia E S, Azambuja P, Gonzalez M S, Rangel E F (2006) Effects of azadirachtin on the development and mortality of Lutzomyia longipalpis larvae (Diptera: Psychodidae: Phlebotominae). J Med Entomol 43: 262-266.

Comer J A, Tesh R B (1991) Phlebotomine sand flies as vectors of vesiculoviruses: a review. Parassitologia 33: 143-150.

Costa C H N, Tapety C M M, Werneck G L (2007) Controle da leishmaniose visceral em meio urbano: estudo de intervenção randomizado fatorial. Rev Soc Bras Med Trop 40: 415-419.

D'amato C, Torres J P M, Malm O (2002) DDT (dicloro difenil tricloroetano): toxicidade e contaminação ambiental - uma revisão. Quim Nova 25: 995-1002. 
Dantas-Torres F (2006) Leishmune ${ }^{\circledR}$ vaccine: The newest tool for prevention and control of canine visceral leishmaniasis and its potential as a transmission-blocking vaccine. Vet Parasitol 141: $1-8$.

Dantas-Torres F, Brandão-Filho S P (2006) Expansão geográfica da leishmaniose visceral no estado de Pernambuco. Rev Soc Bras Med Trop 39: 352-356.

David J R, Stamm L M, Bezerra H S, Souza R N, Killick-Kendrick R, Lima J W O (2001) Deltamethrin-impregnated dog collars have a potent ant feeding and insecticidal effect on Lutzomyia longipalpis and Lutzomyia migonei. Mem Inst Oswaldo Cruz 96: 839-847.

De Barjac H, Larget I, Killick-Kendrick R (1981) Toxicity of Bacillus thuringiensis var. israelensis, serotype H14, to the larvae of phlebotomine sandflies 1981. Bull Soc Pathol Exot 74: 485-489.

Dias E S, França-Silva J C, Silva J C, Monteiro E M, Paula K M, Gonçalves C M, Barata R A (2007) Flebotomíneos (Diptera: Psychodidae) de um foco de leishmaniose tegumentar no estado de Minas Gerais. Rev Soc Bras Med Trop 40: 49-52.

Dougherty M J, Ward R D (1991) Methods of reducing Ascogregarina chagasi parasitaemia in laboratory colonies of Lutzomyia longipalpis. Parassitologia 33: 185-191.

Dye C (1996) The logic of visceral leishmaniasis control. Am J Trop Med Hyg 55: 125-130.

Falcão A L, Falcão A R, Pinto C T, Gontijo C M, Falqueto A (1991) Effect of deltamethrin spraying on the sandfly populations in a focus of American cutaneous leishmaniasis. Mem Inst Oswaldo Cruz 86: 399-404.

França-Silva J C, Barata R A, Costa R T, Monteiro E R M, MachadoCoelho G L L, Vieira E P (2005) Importance of Lutzomyia longipalpis in the dynamics of transmission of canine visceral leishmaniasis in the endemic area of Porteirinha Municipality, Minas Gerais, Brazil. Vet Parasitol 131: 213-220.

Gontijo C M F, Melo M N (2004) Leishmaniose visceral no Brasil: quadro atual, desafios e perspectivas. Rev Bras Epidemiol 7: 338-349.

ICMR Bulletin (2003) Prospects of using products in the control of mosquito vectors. $33: 1-12$.

Kishore K, Kumar V, Kesari S, Dinesh D S, Kumar A J, Das P, Bhattacharya S K (2006) Vector control in leishmaniasis. Indian J Med Res 123: 467-472.

Lainson R, Rangel E F (2005) Lutzomyia longipalpis and the eco-epidemiology of American visceral leishmaniasis, with particular reference to Brazil - a review. Mem Inst Oswaldo Cruz 100: 811-827.

Lewis D J, Lainson R, Shaw J J (1970) Determination of porous rates in phlebotomine sandflies, with special reference to Amazon species. Bull Entomol Res 60: 209-219.

Luitgards-Moura, J F, Castellon Bermudez E G, Rocha A F, Tsouris P, Rosa-Freitas M G (2002) Preliminary assays indicate that Antonia ovata (Loganiaceae) and Derris amazonica
(Papilionaceae), ichthyotoxic plants used for fishing in Roraima, Brazil, have an insecticide effect on Lutzomyia longipalpis (Diptera: Psychodidae: Phlebotominae). Mem Inst Oswaldo Cruz 97: 737-742.

Luz Z M P, Pimenta D N, Schall V T, Rabello A (2003) Evaluation of informative materials on leishmaniasis distributed in Brazil: criteria and basis for the production and improvement of health education materials. Cad Saúde Pública 19: 561-569.

Madeira M F, Uchoa C M A, Leal C A, Silva R M M, Duarte R, Magalhães C M, Serra C M B (2003) Leishmania (Viannia) braziliensis em cães naturalmente infectados. Rev Soc Bras Med Trop 36: 551-555.

Maroli M, Khoury C (2004) Prevention and control of leishmaniasis vectors: current approaches. Parassitologia 46: 211-215.

Maroli M, Mizzon V, Siragusa C, D’oorazi A, Gradoni L (2001) Evidence for an impact on the incidence of canine leishmaniasis by the mass use of deltamethrin-impregnated dog collars in southern Italy. Med Vet Entomol 15: 358-363.

Mazloumi Gavgani A S, Hodjati H, Mohite H, Davies C R (2002) Impact of insecticide impregnated dog collars on rate of zoonotic visceral leishmaniasis infection in children: matched communitybased trial in Iran. Lancet 360: 374-379.

Mestre G L C, Fontes C J F (2007) A expansão da epidemia da leishmaniose visceral no estado de Mato Grosso, 1998-2005. Rev Soc Bras Med Trop 40: 42-48.

Ministério da Saúde. Secretaria de Vigilância em Saúde. Departamento de Vigilância Epidemiológica (2006) Manual de vigilância e controle da leishmaniose visceral. Brasília, Ministério da Saúde, 122p. Available at: http://portal.saude.gov. br/portal/arquivos/pdf/manual_leish_visceral2006.pdf.

Ministério da Saúde. Secretaria de Vigilância em Saúde. Departamento de Vigilância Epidemiológica (2007) Manual de vigilância da leishmaniose tegumentar americana. $2^{\mathrm{a}}$ ed, Brasília, Ministério da Saúde, 184p. Available at: http://portal.saude.gov. br/portal/arquivos/pdf/manual_lta_2ed.pdf.

Monteiro E M, França-Silva J C, Costa R T, Costa D C, Barata R A, Paula E V, Machado-Coelho G L L, Rocha M F, Fortes-Dias C L, Dias E S (2005) Leishmaniose visceral: estudo de flebotomíneos e infecção canina em Montes Claros, Minas Gerais. Rev Soc Bras Med Trop 38: 147-152.

Nascimento J C, Paiva B R, Malafronte R S, Fernandes W D, Galati E A B (2007) Natural infection of phlebotomines (Diptera: Psychodidae) in a visceral-leishmaniasis focus in Mato Grosso do Sul, Brazil. Rev Inst Med Trop Sao Paulo 49: 119-122.

Nery-Guimarães F, Bustamante F M (1954) Aplicação domiciliada de DDT como base da profilaxia das leishmanioses - Estudo de um foco de leishmaniose muco-cutânea cinco anos depois da aspersão periódica com aquele inseticida. Rev Bras Malariol Doen Trop 6: 127-130.

Nogueira MAS, Palmério M (2001) Practice oriented results on use and production of plant extracts andpheromones in integrated and biological pest control. 1 Workshop, Neem and Pheromones, Uberaba,Universidade de Uberaba, 46p. 
Available at: http://www.trifolio-m.de/info_service/workshops/ Brasil_Workshop_1_Abstracts.pdf

Odorizzi R N F M, Galati E A B (2007) Flebotomíneos de várzea do rio Aguapeí, região noroeste do estado de São Paulo, Brasil. Rev Saúde Públ 41: 645-52.

Oliveira S S, Araújo T M (2003) Avaliação das ações de controle da leishmaniose visceral (calazar) em uma área endêmica do estado da Bahia, Brasil (1995-2000). Cad Saúde Pública 19: 1681-1690.

Pessoa F A C, Medeiros J F, Barrett T V (2007) Effects of timber harvest on phlebotomine sand flies (Diptera: Psychodidae) in a production forest: abundance of species on tree trunks and prevalence of trypanosomatids. Mem Inst Oswaldo Cruz 102: 593-599.

Pimenta D N, Leandro A, Schall (V T 2007) A estética do grotesco e a produção audiovisual para a educação em saúde: segregação ou empatia? O caso das leishmanioses no Brasil. Cad Saúde Pública 23: 1161-1171.

Reithinger R, Coleman P G, Alexander B, Vieira E P, Assis G, Davies C R (2004) Are insecticide-impregnated dog collars a feasible alternative to dog culling as a strategy for controlling canine visceral leishmaniasis in Brazil? Int J Parasitol 34: 55-62.

Reithinger R, Davies C R, Cadena H, Alexander B (1997) Evaluation of the fungus Beauveria bassiana as a potential biological control agent against phlebotomine sand flies in Colombian coffee plantations. J Invertebr Pathol 70: 131-135.

Robert L L, Perich M J, Schlein Y, Jacobson J L, Wirtz R A, Lawyer P G, Githure J I (1997) Phlebotomine sand fly control using bait-fed adults to carry the larvicide's Bacillus sphaericus to the larval habitat. J Am Mosq Control Assoc 13: 140-144.

Hynes R K, Boyetchko S M (2006) Research initiatives in the art and science of biopesticide formulations. Soil Biol Biochem 38: 845-849.

Saraiva E M, Barbosa A F, Santos F N, Borja-Cabrera G P, Nico D, Souza L O, Mendes-Aguiar C O, Souza E P, Fampa P, Parra L E, Menz I, Dias Jr J G, Oliveira S M, Palatnik-De-Sousa C B (2006) The FML-vaccine (Leishmune ${ }^{\circledR}$ ) against canine visceral leishmaniasis: a transmission blocking vaccine. Vaccine 24 : 2423-2431.

Secundino N F C, Araújo M S S, Oliveira G H B, Massara C L, Carvalho O S, Lanfredi R M, Pimenta P F P (2002) Preliminary description of a new entomoparasitic nematode infecting Lutzomyia longipalpis sand fly, the vector of visceral leishmaniasis in the New World. J Invertebr Pathol 80: 35-40.

Shaalan E A S, Canyon D, Younes M W F, Abdel-Wahab H, Mansour A H (2005) A review of botanical phytochemicals with mosquitocidal potential. Environ Int 31: 1149-1166.

Sherlock I A (1996) Ecological interactions of visceral leishmaniasis in the state of Bahia. Mem Inst Oswaldo Cruz 91: 671-683.
Srinivasan R, Kalyanasundaram M (2001) Relative efficacy of DEPA and neem oil for repellent activity against Phlebotomus papatasi, the vector of leishmaniasis. J Commun Dis 33: 180-184.

Teodoro U, Santos D R, Santos A R, Oliveira O, Poiani L P, Kühl J P, Lonardoni M V C, Silveira T G V, Monteiro W M, Neitzke H C (2007) Avaliação de medidas de controle de flebotomíneos no Norte do estado do Paraná, Brasil. Cad Saúde Pública 23: 2597-2604.

Teodoro U, Silveira T G V, Santos D R, Santos E S, Santos A R, Oliveira O, Kühl J B (2001) Freqüência da fauna de flebotomíneos no domicílio e em abrigos de animais domésticos no peridomicílio, nos municípios de Cianorte e Doutor Camargo - estado do Paraná - Brasil. Rev Patol Trop 30: 209-233.

Teodoro U, Thomaz-Soccol V, Kühl J B, Santos D R, Santos E S, Santos A R, Abbas M, Dias A C (2004) Reorganization and cleaness of peridomiciliar area to control sand flies (Diptera, Pschodidae, Phlebotominae) in South Brazil. Braz Arch Biol Technol 47: 205-212.

Traore-Lamizana M, Fontenille D, Diallo M, Ba Y, Zeller H G, Mondo M, Adam F, Thonon J, Maiga A (2001) Arbovirus surveillance from 1990 to 1995 in the Barkedji area (Ferlo) of Senegal, a possible natural focus of Rift Valley fever virus. J Med Entomol 38: 480-492.

Valerio L, Maroli M (2005) Valutazione dell'effetto repellente ed anti-feeding dell'olio d'aglio (Allium sativum) nei confronti dei flebotomi (Diptera: Psychodidae). Ann Ist Super Sanita 41: 253-256.

Ximenes M F F M, Silva V P M, Queiroz P V S, Rego M M, Cortez A M, Batista L M M, Medeiro A S, Jeronimio S M B (2007) Flebotomíneos (Diptera: Psychodidae) e leishmanioses no Rio Grande do Norte, Nordeste do Brasil - reflexos do ambiente antrópico. Neotrop Entomol 36: 128-137.

Xu F, Chen H, Travassos da Rosa A P, Tesh R B, Xiao S Y (2007) Phylogenetic relationships among sandfly fever group viruses (Phlebovirus: Bunyaviridae) based on the small genome segment. J Gen Virol 88: 2312-2319.

Wahba M M (2000) The influence of Bacillus sphaericus on the biology and histology of Phlebotomus papatasi. J Egypt Soc Parasitol 30: 315-323.

Wahba M M, Labib I M, El Hamshary E M (1999) Bacillus thuringiensis var. israelensis as a microbial control agent against adult and immature stages of the sandfly, Phlebotomus papatasi under laboratory conditions. J Egypt Soc Parasitol 29: 587-97.

Warburg A (1991) Entomopathogens of phlebotomine sand flies: Laboratory experiments and natural infections. J Invertebr Pathol 58: 189-202.

Werkhauser M (2004) Prevenção. Clin Vet 49: 21.

Received 20/II/08. Accepted 05/III/09. 